\title{
The Information System of Vertically Integrated Structures as a Pillar of Entrepreneurship in the Information Society
}

\author{
Olena Kryvoruchko ${ }^{1}$, Svitlana Rzayeva ${ }^{2}$, Oleksandr Kozik ${ }^{3}$ \\ ${ }^{1,2,3}$ Kyiv National University of Trade and Economics, 19, Kyoto St., Kyiv 02156, Ukraine
}

\begin{abstract}
In the article the authors analyze peculiarities of the concept of creating information system of vertically integrated structures as a pillar of entrepreneurship in the information society.
\end{abstract}

Keywords: information system, information society, vertically integrated enterprise, ERP-system, OLAP-technology, BPM-system, software, SOA information architecture

\section{Introduction}

The dynamics of the external economic environment compels enterprises to transform themselves to the entirely complex system requiring new management methods which are profoundly based on processing the proliferation of information in the real time. We can therefore state that the enterprise performance efficiency can be achieved through a single corporate information system that integrates financial management, human resources, supply and distribution of goods and services. Such systems are namely viewed as a means of achieving major business objectives, such as improving the quality of products and services; extending and increasing a market share and withstanding fierce competition.

It is next to impossible to implement the integration of domestic enterprises into the global economy without introducing innovative processes, which are entirely aimed at changing priorities of using information resources. They are not supposed to be used as fiscal functions, but mainly as a source of providing and supporting decision-making processes in all areas of the company. Only under these conditions does the information system of a vertically integrated company (association) acquire its strategic importance, as investments aimed at its development are the most promising and lucrative in the information society.

\section{The Problem Solving}

The peculiarity of creating the information system of a vertically integrated company (association) is the use of the term «Enterprise-wide Resource Planning» - ERP). The ERP-systems is namely based on the principle of creating a single database repository containing all the corporate business information, mainly the day-to day financial information, production and human resources data. The availability of the single corporate repository eliminates the necessity to transfer data from one system to another (e.g. from the production system to the financial or human resources ones) and provides a simultaneous access of the authorized personnel to the information. The purpose of the ERP-systems is not only to enhance an enterprise's production management, but also reduce the cost and efforts of supporting its internal information flows. The introduction of such a system makes it possible to significantly reduce transaction costs.

\section{The integrated information environment}

Combining the ERP-system with online analytical processing technology (OLAP), Balanced Score Card and a system of Value Management provides the emergence and development of BPM (Business Performance Management) which is viewed as an efficient business management technique permitting to combine the business operating performance of all its association members with efficient implementation of the vertical links among them.

The efficient functioning of the entire information system in an organization significantly depends on the flexibility and quality of information system of a vertically integrated company; its development is supposed to be carried out in compliance with the vertically integrated union. The implementation of integrated approach eliminates errors at the stage of the information systems design and increases the whole enterprise performance efficiency.

Using modern information technologies companies face issues arising due to exchange of information among various units (participants) of a vertically integrated structure. In corporate structures of a holding type these problems are sorted out by implementing a unified corporate information system, whereas for contractual forms of integration and non-rigid corporate groups, the issue of consolidation of information sources is quite of current concern.

The solution to the above mentioned issue is using CALS technologies (Continuous Acquisition and Life cycle Support), which are interpreted as information support of product life cycle. The essence of this technology lies in implementing integrated information environment via electronic data transfer facilities for all stages of the product life cycle.[3]

The integrated information environment is a specifically purpose-built data depository with a set of distributed databases, which are subject to common rules of information 


\section{International Journal of Science and Research (IJSR) \\ ISSN (Online): 2319-7064}

Index Copernicus Value (2013): 6.14 | Impact Factor (2015): 6.391

collection, storage, updating, search and transmission through which the consolidation of information among all participants of the vertically integrated structure is fulfilled. An integrating link will be a database management system based on the method of service-oriented architecture. This will combine various business information systems into a single information space of a vertically integrated structure.

The process of vertical integration of applying serviceoriented architecture will reduce risks associated with the introduction of information technologies projects in entities, significantly contribute to faster development and integration of composed applications and provide continuous information system support. Applying the most widespread information sharing services, such as the World Wide Web, XML and work with multidimensional databases will enable companies to efficiently handle large data sets interactively. Hence, software built on the concept of CALS, is based on the strategy of systematical improving the efficiency and profitability of vertically integrated formations through the introduction of modern methods of information exchange among all parties of the vertically integrated structure.[2]

In order to evaluate the software and information flows among the units of a particular vertically integrated entity it is accepted to apply an approach of the classic statistical information theory. Entropy can be estimated as the mathematical expected share of information $I\left(a_{i}\right)$ using the Shannon's formula:

$$
H(A)=\sum_{i=1}^{n} p\left(a_{i}\right) I\left(a_{i}\right)=-\sum_{i=1}^{n} p\left(a_{i}\right) \log _{2} p\left(a_{i}\right) ;
$$

where $A=\left(a_{1}, a_{2}, \ldots, a_{i}, \ldots, a_{n}\right)$ - a discrete source of statistically independent messages, such as the management impact in terms of orders, etc.;

$p\left(a_{i}\right)$ - probability of $i$-message, namely the probability of the same perception of managerial influence of all members of a vertically integrated structure.[1]

So, the creation and development of information infrastructure results in establishing an enterprise's single information space, which particularly reflects in vertically integrated structures united by information flows among all participants of business processes.

\section{Conclusion}

The use of modern information systems has become not only desirable and the rule of the day, but also a necessary precondition for companies' establishing and functioning with a vertical form of integration, which involves improving and restructuring information infrastructure.

Information support (relevant software) of vertical integration involves the creation of companies' common information space that make up the association, using modern information technologies aimed at developing information infrastructure. These technologies in the near future will be an objectively necessary precondition for the establishment of vertically integrated structures as a management basis in the information society.

\section{References}

[1] Lapin A. V. Vertical integration as a means of overcoming information asymmetry / Lapin A. V. // Bulletin of Sumy National Agricultural University. Section: Economics and Management. - 2015. - Vol. 5 (64). - P. 235-238.

[2] S.V. Tsiutsiura, O.V. Kryvoruchko, M.I. Tsiutsiura The theoretical basis and essence of management decisions. Models of taking management decisions // Scientific issues «Managing the development of complex systems» / - Issue 9 - c. Kyiv, 2015. - P.53-58

[3] Rzaiev D.O., Rzaieva S.L. Peculiarities of developing a model of information security // Scientific issues of the V-th International Scientific conference "Monitoring, modeling and managing emergent economy" 26-28 April 2016 / The Ministry of Education and Science of Ukraine, Cherkasy National University named after B. Khmelnitsky, Kyiv National Economic University named after Vadym Hetman, Odessa National Economic University; [editors.: V. Soloviev (responsible for the issue) etc.]. - C. Cherkassy Brama: Ukraine, 2016 - P.167-168.

[4] Melnychenko S. V., N. L. Zikii Restructuring - an innovative course of business development. / Problems and perspectives of innovative activity in Ukraine: // IX-th International Business Forum (Kyiv, March 17, 2016.) / Editor Mazaraki A. A. - c. Kyiv, 2016. - P.113-114

\section{Author Profile}

Mrs. Olena Kryvorychko. After graduating from Kyiv Technological Institute of Food Industry in 1991, Mrs. O. Krivoruchko acquired the qualification of engineer-economist, specialty "economics and industrial organization of food." From 1991 till 2000 she worked in Ukraine's leading food manufacturing companies as an economist. Since 2000 she has been working at Kyiv National University of Trade and Economics. In 2003 she received the degree of Candidate of Technical Sciences in the field of information technology, in 2008 was named Associate professor of Economic Cybernetics and informative systems. In 2015 she defended her doctorial research and received a degree of Doctor of Science in Project Management and programs. She is currently working as head of the Department of Software Engineering and Information System Works at Kyiv National University of Trade and Economics.

Mrs. Svitlana Rzayeva started her teaching carrier in 1998 as an assistant at the department of information
systems and networks in Kyiv National University of
Trade and Economics. In 2005 she defended a thesis
on specialty 05.13.06 - Automated Control Systems 1998 as an assistant at the department of information
systems and networks in Kyiv National University of
Trade and Economics. In 2005 she defended a thesis
on specialty 05.13.06 - Automated Control Systems 1998 as an assistant at the department of information
systems and networks in Kyiv National University of
Trade and Economics. In 2005 she defended a thesis
on specialty 05.13.06 - Automated Control Systems 1998 as an assistant at the department of information
systems and networks in Kyiv National University of
Trade and Economics. In 2005 she defended a thesis
on specialty 05.13.06 - Automated Control Systems Candidate of Technical Sciences,. In 2011 she was awarded the degree of Candidate of Technical Sciences. Svitlana Rzayeva is currently working as an associate professor at the department of software engineering and information systems.

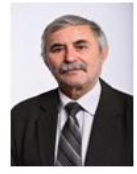

Mr.Oleksandr Kozik graduated from Kyiv Polytechnic Institute, Ukraine, in 1973, specialty an electronic equipment engineer. By 2000 he had worked at Kyiv Institute of Automation as an engineer, head of the laboratory and senior researcher. Since 2000 he has been lecturing at the Department of Software Engineering and Information Systems at Kyiv National University of Trade and Economics. 